\title{
Erratum to: Reduplication in a computational HPSG of Hausa
}

\section{Berthold Crysmann ${ }^{1}$}

Published online: 4 October 2017

(C) Springer Science+Business Media B.V. 2017

\section{Erratum to: Morphology \\ DOI 10.1007/s11525-017-9306-y}

This article has been corrected. During article processing errors were made in the data of Fig. 7. Figure 7 has been updated in the article itself and the current version should be regarded as the final version by the reader.

The online version of the original article can be found under doi:10.1007/s11525-017-9306-y.

\section{B. Crysmann}

crysmann@linguist.univ-paris-diderot.fr

1 Laboratoire de linguistique formelle, CNRS, Case 7031, 5 rue Thomas Mann, 75205 Paris cedex 13, France 